\title{
lodine intake and status in two groups of Norwegians
}

\author{
Lisbeth Dahl', Helle Margrete Meltzer², jill Anette Opsahl' and \\ Kåre Julshamn'
}

'National Institute of Nutrition and Seafood Research (NIFES), Bergen, Norway; ${ }^{2}$ Division of Environmental Medicine, Norwegian Institute of Public Health, Oslo, Norway

\section{Abstract}

Objective: To evaluate the ranges of iodine intake and iodine status in two subgroups of the Norwegian population.

Design: The participants in the Tromsø group $(n=63)$ had a normal diet. The participants in the Bergen group $(n=44)$ comprised people with a variable intake of fish and dairy products.

Results: The iodine intake varied from 56 to $318 \mu \mathrm{g}$ day ${ }^{-1}$ in the Tromsø group and from 30 to $427 \mu \mathrm{g} \mathrm{day}^{-1}$ in the Bergen group. Median intake of iodine $\left(162 \mu \mathrm{g}_{\text {day }}{ }^{-1}\right)$ in the Troms $\varnothing$ group was significantly higher than in the Bergen group $\left(89 \mu \mathrm{g} \mathrm{day}^{-1}\right)(p<0.001)$. Urinary iodine concentration varied from 38 to $572 \mu \mathrm{g}$ $1^{-1}$ with a median value of $117 \mu \mathrm{g}^{-1}$ in the Tromsø group. Median iodine excretion in the Bergen group was $96 \mu \mathrm{g} 24 \mathrm{~h}^{-1}\left(85 \mu \mathrm{g}^{-1}\right)$ and varied from 16 to $316 \mu \mathrm{g} 24 \mathrm{~h}^{-1}$. Median serum thyroid-stimulating hormone was $1.6 \mathrm{mIU}^{-1}$ in the Tromsø group and $1.4 \mathrm{mIU}^{-1}$ in the Bergen group. Median free thyroxine in serum was significantly higher in the participants from Tromsø $\left(15 \mathrm{pmol} 1^{-1}\right)$ than in those from Bergen $(12 \mathrm{pmol}$ $\left.1^{-1}\right)$.

Conclusions: Regular intake of dairy products and/or fish products is important to meet the iodine requirements in the Norwegian diet. Although the iodine intake was found to be in the intake range of sufficient iodine intake of most of the participants in the two groups, there may exist population groups with a very low average intake of iodine.

Keywords: Diet; iodine; iodine excretion; Norwegians; thyroid hormones

Received: 23 May 2003; Revised: 16 July 2003; Accepted: 29 Aug. 2003

\section{Introduction}

Iodine is an essential trace element of great importance in human nutrition. The thyroid gland is dependent on iodine for the synthesis of the thyroid hormones thyroxine $\left(\mathrm{T}_{4}\right)$ and tri-iodothyronine $\left(\mathrm{T}_{3}\right)(1)$. Monitoring of iodine status, either by estimating dietary iodine intake or by measuring urinary iodine excretion of a population, is important to public health, as both low and high iodine intakes are characterized by a variety of adverse health effects (2-4). Levels of thyroid-stimulating hormone (TSH) and free $\mathrm{T}_{4}$ in serum are considered to be indicators of iodine status and long-term iodine intake (5). The disorders induced by iodine deficiency constitute a major nutritional problem in the world and about 2.2 billion people in 130 countries are at risk from iodine deficiency (6). The most common method to eliminate iodine deficiency diseases is iodine supplementation, using salt as the vehicle (7).

The public health implications of iodine intake in Norway have moved from the historical problem of endemic goitre described during the 1930s and 1940s (8) to satisfactory iodine intake when measured as levels of iodine in urine in small groups of Norwegians (9). The recommended daily intake of iodine is $150 \mu \mathrm{g}$ for adults, whereas the lowest and maximum intakes per day are $70 \mu \mathrm{g}$ and $1 \mathrm{mg}$, respectively, in the Nordic countries (10). The only study that calculated the iodine intake in the diet of adults and children showed satisfactory iodine intake in the majority of the Norwegian population (11). In the Norwegian diet milk and dairy products are the main sources of iodine owing to fortification of iodine to cow fodder combined with a daily or frequent intake of milk and dairy products $(9,11$, 
12). Marine fish and other marine products are also important contributors to the iodine intake in Norway owing to their high iodine content (11, 13). Certain brands of table salt in Norway are iodine enriched with $5 \mu \mathrm{g} \mathrm{I} \mathrm{g}{ }^{-1} \mathrm{NaCl}$ (14), an amount too low to contribute significant amounts of iodine to the diet (9). To the authors' knowledge, dietary iodine intake, iodine excretion and indicators of iodine status in the blood have never been monitored together in studies of iodine status in Norway.

The aim of the present study was to assess the iodine intake and status in two selected groups of Norwegians by estimating the dietary iodine intake, urinary iodine excretion, and TSH and free $\mathrm{T}_{4}$ in serum. This was done to evaluate the range of possible iodine intakes and statuses in a population considered to be iodine replete.

\section{Materials and methods}

\section{Subjects and study design in Tromsø}

The majority of the subjects invited by post to the study in Tromsø had previously participated in other studies and were expected to have a normal diet. Seventy-seven Norwegians aged 23-64 years living in Tromsø volunteered to participate. Blood samples were taken before 10.00 a.m. from the participants in April 1999. At the same time a specimen of morning urine was collected and the participants were requested to fill in a dietary food frequency questionnaire (FFQ) within 1 week. Fourteen subjects in Tromsø did not return the FFQ, and results from TSH and free $\mathrm{T}_{4}$ in serum, urinary iodine concentration and dietary iodine intake are therefore reported for 63 participants (35 men, 28 women). The characteristics of the participants are listed in Table 1. Written consent was obtained from each person. The Regional Ethic Research Committee of North Norway (REC North) approved the study.

Table I. Characteristics of participants in Tromsø and in Bergen

\begin{tabular}{lll}
\hline & Tromsø & Bergen \\
\hline No. of participants (men/women) & $35 / 28$ & $9 / 35$ \\
Age (years) & & \\
Body mass index $\left(\mathrm{kg} / \mathrm{m}^{2}\right)^{\text {a }}$ & $45 \pm 9$ & $35 \pm 8$ \\
Daily smoking (men/women) & $25 \pm 3$ & $24 \pm 5$ \\
\hline
\end{tabular}

\footnotetext{
${ }^{\mathrm{a}}$ Figures are mean \pm SD.
}

\section{Subjects and study design in Bergen}

Subjects with little or no fish and dairy products in their diet, as well as high consumers of the same food groups, were requested for the study in Bergen. An invitation was sent to 384 members of the Norwegian Asthma and Allergy Association (NAAF) with residence in the municipality of Bergen. Of the 61 subjects who responded, 44 subjects (9 men, 35 women) aged 21-49 years completed the study in March 2001. Participants in Bergen were requested to collect $24 \mathrm{~h}$ urine (i.e. collect all urine after the morning urine and continue to collect all urine including the morning urine on the following day). The FFQ was delivered together with the $24 \mathrm{~h}$ urine on the morning on which the blood sample was taken. The characteristics of the participants are listed in Table 1. Written consent was obtained from each person. The Regional Research Ethics Committee of West Norway (REC West) approved the study.

\section{Food frequency questionnaires}

Dietary intake was assessed by two different FFQs. The FFQ used in the study in Tromsø was designed to collect data on the habitual diet during a year, and included questions about how often and how much is eaten of the 180 most commonly consumed food items and dishes in Norway. The FFQ used in Troms $\varnothing$ has been validated (15-18). The FFQ used in Bergen was developed especially for the study and focused on last week's intake of milk and dairy products and last month's intake of fish and fish products. The FFQ used in Bergen was not validated before it was used. Both FFQs included some questions about the use of different types of dietary supplements.

\section{Calculation of dietary iodine intake}

The iodine contribution from each foodstuff was calculated on the basis of frequency of consumption, portion size and iodine content of the specific food, and given in $\mu \mathrm{g}$ iodine $\mathrm{day}^{-1}$. The iodine concentrations of the foodstuffs reported by Dahl et al. 2003 (11) were used, except for milk. The mean iodine concentration of milk from the winter season $\left(231 \mu \mathrm{g} \mathrm{1^{-1 }}\right)$ (12) was used in Tromsø and Bergen. The iodine concentration of tap water $\left(2 \mu \mathrm{g}^{-1}\right)$ was used for all kinds of beverages $(19,20)$.

The iodine intake from fish and fish products reflects the participants' intake of lean fish, fatty fish, fresh water fish, fish products, shellfish and fish 
as sandwich spread. The iodine intake from milk reflects the participants' intake of all types of milk (e.g. skimmed milk, low-fat milk, organic milk, milkshake or curled milk). The iodine intake from dairy products reflects the participants' intake of cheese, whey cheese, yoghurt, sour cream and cream. The iodine contribution from other foodstuffs includes the daily intake of bread, cereal products, pasta, cakes, vegetables, fruit, meat and meat products, egg, oils and fats and all types of beverages. To correct for the iodine contribution from "other foodstuff" in Bergen, which only focused on intake of fish and fish products, milk and dairy products, $30 \mu \mathrm{g}$ day ${ }^{-1}$ was added to every daily iodine intake. This addition was based on the average daily intake of relevant foods in the Norkost Survey, which included data on the average intake of foods in a representative sample of Norwegians (21). The FFQ used in the Norkost Survey was the same as the one used in Tromsø.

\section{Analysis of iodine and creatinine in urine}

Urinary iodine concentration was determined by inductively coupled plasma mass spectrometry (ICP-MS) using a Perkin-Elmer SCIEX Elan 5000A ICP-MS (Toronto, Canada) $(13,22)$. Certified reference material (Seronorm ${ }^{\mathrm{TM}}$ Trace Elements; Nycomed, Norway) of human urine was included in each analytical series to control the systematic errors. Urinary creatinine was determined in participants in Bergen with a standard colorimetric method based on Jaffes reaction (23). The concentration of creatinine was measured spectrophotometerically (Technicon RA 1000) together with a standard reference material (Bayer Testpoint $^{\mathrm{TM}}$ assayed chemistry control 1 ).

\section{Analysis of thyroid-stimulating hormone and free thyroxine in serum}

Serum TSH of subjects in Tromsø was determined using the AxSYM Ultrasensitive hTSH II system. Serum free $T_{4}$ of subjects in Tromsø was determined using the AxSYM Free $T_{4}$ system. Both analyses were based on Microparticle Enzyme Immunoassay (MEIA) Technology (Abbot Laboratories, Abbot Park, IL, USA). Serum TSH and free $\mathrm{T}_{4}$ of subjects in Bergen were analysed using Auto DELFIA (Turku, Finland) with Auto DELFIA hTSH kit and Auto DELFIA with free $\mathrm{T}_{4}$ kit. The laboratory reference range of TSH and free $\mathrm{T}_{4}$ was $0.2-4.0$ mIU $1^{-1}$ and $9-26 \mathrm{pmol}^{-1}$, respectively, in
Tromsø, whereas in Bergen the laboratory reference range was $0.3-5.0 \mathrm{mIU}^{-1}$ and $7.6-19.7 \mathrm{pmol}^{-1}$, respectively.

\section{Statistical analysis}

Results from Tromsø and Bergen are mainly presented separately, as different methods are used in the two towns. Data are mainly reported as median values with ranges in parentheses. Statistical analyses were performed using Statistica 4.5 (Statsoft, USA, 1999). A confidence level of $95 \%$ was used throughout all statistical tests (i.e. $p<0.05$ was considered significant). A Kolmogorov-Smirnov test was used to assess normality of distribution. The homogeneity of variance was tested using Levene's test. Only iodine concentration in urine in Tromsø was not normally distributed. In cases where one-way ANOVA showed significant differences, Tukey's HSD test was used to find which groups showed significant differences to each other. Spearman's rank order test was used for correlation analysis.

\section{Results}

lodine nutrition in Tromsø and Bergen

Dietary iodine intakes, urinary iodine concentrations of participants in Tromsø and urinary iodine excretion of participants in Bergen, as well as the hormones, are shown in Table 2. The iodine intake of men was significantly higher than that of women in Troms $\varnothing(p<0.001)$. The median iodine intake of men in Tromsø was above the recommended daily intake of iodine set at $150 \mu \mathrm{g}(10)$, whereas the iodine intake of women was below the recommendation. The iodine intake in relation to the energy intake in Tromsø corresponded to $170 \mu \mathrm{g} 10 \mathrm{MJ}^{-1}$ in men and to $142 \mu \mathrm{g} 10 \mathrm{MJ}^{-1}$ in women. The iodine intake $\left(\mu \mathrm{g} \mathrm{day}^{-1}\right)$ in Tromsø showed no correlation with the urinary iodine concentration $\left(\mu \mathrm{g}^{-1}\right)(p>0.05)$. Only one participant out of 64 in Troms $\varnothing$ had a urinary iodine concentration $<50$ $\mu \mathrm{g} 1^{-1}$, while $25 \mathrm{had}<100 \mu \mathrm{g} 1^{-1}$.

The dietary iodine intake of participants in Bergen was significantly lower than that of participants in Tromsø $(p<0.001)$ (Table 2$)$. The men in Bergen had significantly higher iodine intake than women in Bergen $(p<0.001)$. A significant correlation between iodine intake $\left(\mu \mathrm{g} \mathrm{day}^{-1}\right)$ and urinary iodine excretion $\left(\mu \mathrm{g} 24 \mathrm{~h}^{-1}\right)$ was found in Bergen $(r=0.56)(p<0.001)$. A significant correlation was 
Table 2. lodine intake determined from food frequency questionnaires, urinary iodine concentration (Tromsø), urinary iodine excretion (Bergen), serum thyroid-stimulating hormone (TSH) and serum free thyroxine $\left(\mathrm{T}_{4}\right)$ in men, women and all participants in Tromsø and Bergen

\begin{tabular}{|c|c|c|c|c|c|c|}
\hline & \multicolumn{3}{|l|}{ Tromsø } & \multicolumn{3}{|l|}{ Bergen } \\
\hline & Men & Women & All & Men & Women & All \\
\hline lodine intake $\left(\mu \mathrm{g} \mathrm{day}^{-1}\right)$ & $187(66-318)^{\mathrm{a}}$ & $114(56-290)^{\mathrm{b}}$ & $162(56-318)$ & $147(52-427)^{\mathrm{a}}$ & $75(30-291)^{c}$ & $89(30-427)$ \\
\hline Urinary iodine $\left(\mu \mathrm{gl}^{-\mathrm{I}}\right)$ & $132(38-572)$ & $112(57-314)$ & $117(38-572)$ & $106(25-182)$ & $82(8-348)$ & $85(8-348)$ \\
\hline Urinary iodine $\left(\mu \mathrm{g} 24 \mathrm{~h}^{-\mathrm{I}}\right)$ & - & - & - & $140(33-235)$ & $79(16-316)$ & $96(16-316)$ \\
\hline Urinary lodine ( $\mu \mathrm{g} \mathrm{I} \mathrm{g}^{-1}$ creatinine) & - & - & - & $91(47-122)$ & $98(|3-32|)$ & $94(13-321)$ \\
\hline TSH $\left(\mathrm{mlU} \mathrm{I}^{-1}\right)$ & I. $4(0.6-3.5)$ & $1.8(0.8-3.9)$ & $1.6(0.6-3.9)$ & $1.3(0.6-2.9)$ & $1.3(0.5-4.2)$ & $1.4(0.5-4.2)$ \\
\hline Free $\mathrm{T}_{4}\left(\mathrm{pmol} \mathrm{I}^{-1}\right)$ & $15(12-22)$ & $15(12-17)$ & $15(12-22)$ & $12(10-16)$ & $12(10-15)$ & $12(10-16)$ \\
\hline
\end{tabular}

Data are shown as median (range).

Different superscript letters denote significant differences between gender in the same row $(p<0.001)$ (ANOVA, Tukey's test).

also found between the daily iodine intake and urinary iodine excretion expressed as $\mu \mathrm{g} 1^{-1}$ or $\mu \mathrm{g} \mathrm{I}$ $\mathrm{g}^{-1}$ creatinine $(r=0.53$ and 0.52 , respectively) in Bergen $(p<0.001)$ (Table 2). Of the participants in Bergen, two out of 44 had a urinary iodine excretion $<20 \mu \mathrm{g} 24 \mathrm{~h}^{-1}, 11<50 \mu \mathrm{g} 24 \mathrm{~h}^{-1}$ and $21<100 \mu \mathrm{g} 24 \mathrm{~h}^{-1}$.

Even though no significant differences in serum TSH between men and women were found in Tromsø, there was a tendency towards higher TSH values in women than in men. The range of serum TSH in Tromsø and Bergen was similar and the serum TSH was higher in Tromsø than in Bergen, without being significant. Non-smokers and smokers in Tromsø did not differ significantly with regard to TSH in serum. The mean \pm SD values for serum TSH in non-smokers and smokers in Tromsø were $1.9 \pm 0.8$ and $1.6 \pm 0.8$, respectively. The serum free $\mathrm{T}_{4}$ concentration in Tromsø was significantly higher than the serum free $\mathrm{T}_{4}$ concentration of the participants in Bergen $(p<0.001)$.

Table 3 shows the iodine content in urine and levels of TSH and free $\mathrm{T}_{4}$ in serum in relation to three different levels of dietary intake of iodine of participants in Tromsø and Bergen. The urinary iodine concentration in Tromsø as well as the iodine excretion in Bergen increased with increasing dietary iodine intake, but significant differences were only found in the study in Bergen (Table 3). The serum TSH concentration showed a decreasing trend with increasing iodine intake in both studies; however, it was not significant. The serum TSH concentrations of non-smokers in Tromsø were found to be lower than those of smokers with iodine intake in the range of $>70-150 \mu \mathrm{g} \mathrm{day}^{-1}$ or with iodine intake $>150 \mu \mathrm{g}$ day $^{-1}$.
Table 3. Urinary iodine concentration (Tromsø), urinary iodine excretion (Bergen), serum thyroid-stimulating hormone (TSH) and serum free thyroxine $\left(\mathrm{T}_{4}\right)$ in three different categories of iodine intake in participants in Tromsø and Bergen

\begin{tabular}{|c|c|c|c|}
\hline & \multicolumn{3}{|c|}{ lodine intake $\left(\mu \mathrm{g} \mathrm{day}^{-I}\right)$} \\
\hline & $<70$ & $70-150$ & $>150$ \\
\hline \multicolumn{4}{|l|}{ Tromsø } \\
\hline$n(\%)$ & 5 & 41 & 54 \\
\hline Urinary iodine $\left(\mu g \mathrm{I}^{-1}\right)$ & $85(38-86)$ & $115(59-264)$ & $132(90-572)$ \\
\hline $\mathrm{TSH}\left(\mathrm{mlU} \mathrm{I}^{-1}\right)$ & $1.9(1.7-3.0)$ & $1.5(0.7-3.8)$ & $1.6(0.6-3.9)$ \\
\hline Free $\mathrm{T}_{4}\left(\mathrm{pmol} \mathrm{I}^{-1}\right)$ & $16(15-17)$ & $15(13-18)$ & $15(12-22)$ \\
\hline \multicolumn{4}{|l|}{ Bergen } \\
\hline$n(\%)$ & 39 & 34 & 27 \\
\hline $\begin{array}{l}\text { Urinary iodine ( } \mu \mathrm{g} 24 \\
\mathrm{~h}^{-1} \text { ) }\end{array}$ & $46(19-186)^{a}$ & $81(16-288)^{a b}$ & $176(97-316)^{c}$ \\
\hline Urinary iodine $\left(\mu g \mathrm{I}^{-1}\right)$ & $33(11-182)^{\mathrm{a}}$ & $71(8-163)^{\mathrm{ab}}$ & $110(68-209)^{c}$ \\
\hline $\mathrm{TSH}\left(\mathrm{mlU} \mathrm{I}^{-1}\right)$ & $1.6(1.0-4.2)$ & $1.4(0.5-2.2)$ & $1.3(0.6-2.8)$ \\
\hline Free $\mathrm{T}_{4}\left(\mathrm{pmol} \mathrm{I}^{-\mathrm{I}}\right)$ & $12.0(9.6-16.0)$ & $13.0(|1.1-| 4.8)$ & $11.4(9.7-14.8)$ \\
\hline
\end{tabular}

Data are shown as median (range).

Different superscript letters denote significant differences between iodine intake groups in the same row $(p<0.00 \mathrm{I})$ (ANOVA, Tukey's test).

In Fig. 1 the participants in Tromsø and Bergen are divided into three different categories based on the total intake of iodine, and the figure shows the contribution of iodine from fish and fish products, milk and dairy products and other foodstuffs. Participants with daily iodine intake $<70 \mu \mathrm{g}$ are given as $\mathrm{A}$, whereas $\mathrm{B}$ refers to an iodine intake between 70 and $150 \mu \mathrm{g}$, and $\mathrm{C}$ to an iodine intake $>150 \mu \mathrm{g} \mathrm{day}^{-1}$. In Tromsø the iodine intake from milk and dairy products was significantly higher than the iodine intake from fish and fish products $(p<0.001)$ and from other foodstuffs $(p<0.001)$ in all three levels of iodine intake investigated (Fig. 1). The iodine contribution from fish and fish products 


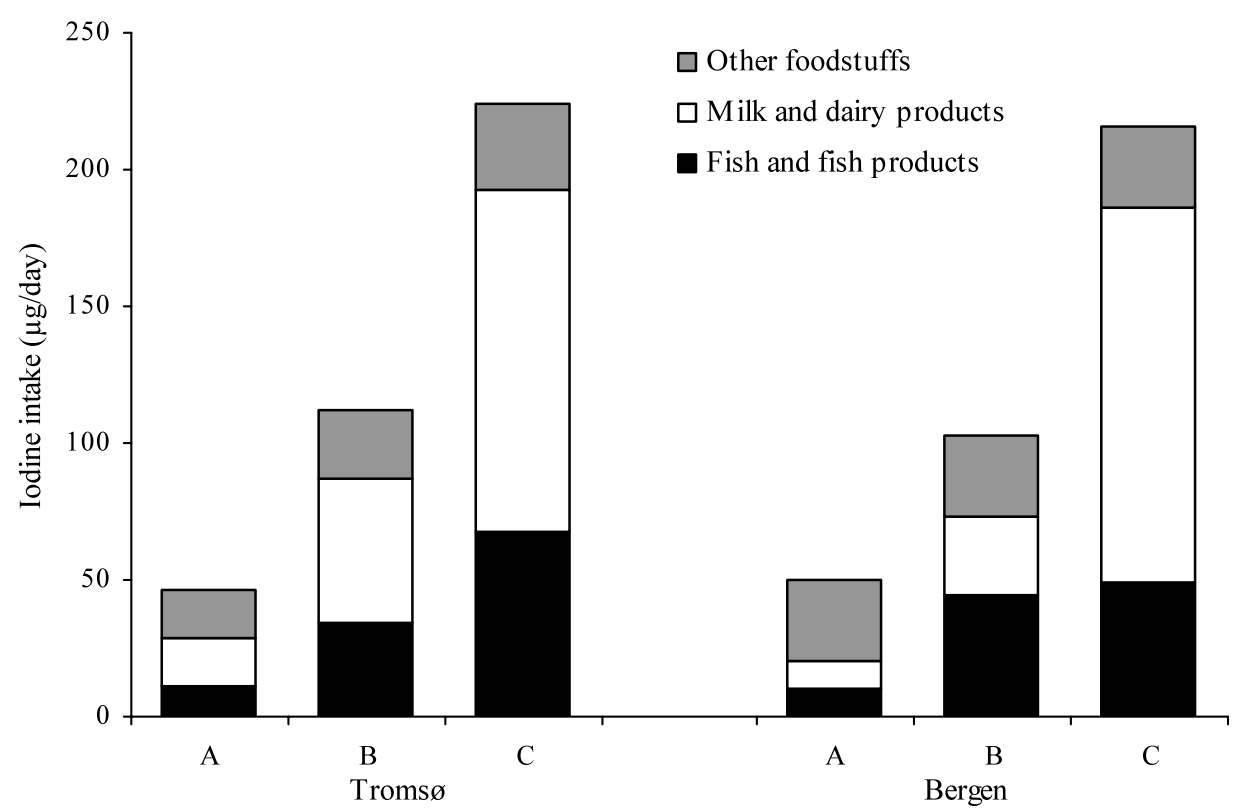

Fig. 1. Iodine intake from fish and fish products, milk and dairy products and other foodstuffs categorized after total iodine intake $(\mathrm{A}=<70$ $\mu \mathrm{g} \mathrm{day}^{-1}, \mathrm{~B}=70-150 \mu \mathrm{g}$ day $^{-1}$ and $\mathrm{C}=>150 \mu \mathrm{g} \mathrm{day}^{-1}$ ).

in Tromsø was significantly higher than the iodine contribution from other foodstuffs in the highest level of iodine intake ( $p=0.006)$ (Fig. 1).

The iodine contribution from milk and dairy products in Bergen was significantly higher than from fish and fish products $(p<0.001)$ and other foodstuffs $(p<0.001)$ in participants with an iodine intake $>150 \mu \mathrm{g} \mathrm{day}^{-1}$ (Fig. 1). The contribution of iodine from fish and fish products was similar in the two highest levels of iodine intake in Bergen (Fig. 1). The iodine contribution from other foodstuffs was significantly higher than from milk and dairy products $(p<0.001)$ and fish and fish products $(p<0.001)$ in participants in Bergen with an iodine intake $<70 \mu \mathrm{g} \mathrm{day}^{-1}$ (Fig. 1).
Iodine intakes, urinary iodine and hormone values are shown in Table 4 for participants in Troms $\varnothing$ and in Table 5 for participants in Bergen, based on the intake of milk and dairy products and fish and fish products. The iodine intake increased with increasing intake of milk and dairy products and fish and fish products in Tromsø (Table 4). The iodine intake as well as the iodine excretion increased with increasing intake of milk and dairy products and/or increasing intake of fish and fish products in Bergen (Table 5).

Dietary supplements were used among 79\% $(n=$ $50)$ of participant in Tromsø and of $68 \%(n=30)$ participants in Bergen. The most frequently used supplements were cod liver oil, vitamin C, vitamin E

Table 4. lodine intake, urinary iodine concentration, serum thyroid-stimulating hormone (TSH) and serum free thyroxine ( $\left.\mathrm{T}_{4}\right)$ in relation to dairy and fish intakes in Tromsø

\begin{tabular}{|c|c|c|c|c|}
\hline Intake per day (\% of studied groups) & $\begin{array}{l}\text { lodine intake } \\
\left(\mu \mathrm{g} \mathrm{day}^{-1}\right)\end{array}$ & $\begin{array}{l}\text { Urinary iodine } \\
\left(\mu \mathrm{g} \mathrm{I}^{-1}\right)\end{array}$ & 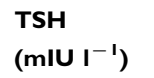 & $\begin{array}{l}\text { Free } \mathrm{T}_{4} \\
\left(\mathrm{pmol} \mathrm{I^{-I }}\right)\end{array}$ \\
\hline$<\mathrm{I} 50 \mathrm{~g}$ milk and dairy products and & $71(56-93)^{a}$ & $86(38-166)$ & $1.8(1.3-3.0)$ & $15.6(15.1-16.0)$ \\
\hline \multicolumn{5}{|l|}{$<60 \mathrm{~g}$ fish and fish products $(9.5)$} \\
\hline$<150 \mathrm{~g}$ milk and dairy products and & $104(99-171)^{b}$ & $142(60-246)$ & $1.5(0.7-3.4)$ & $15.0(13.0-17.0)$ \\
\hline \multicolumn{5}{|l|}{$>60 \mathrm{~g}$ fish and fish products (II) } \\
\hline$>150 \mathrm{~g}$ milk and dairy products and & $122(90-290)^{c}$ & $98(57-265)$ & $1.7(0.6-3.8)$ & $15.5(13.0-18.0)$ \\
\hline \multicolumn{5}{|l|}{$<60 \mathrm{~g}$ fish and fish products $(29)$} \\
\hline$>150 \mathrm{~g}$ milk and dairy products and & $208(104-318)^{d}$ & $153(82-572)$ & $1.6(1.1-3.9)$ & $15.2(11.9-22.0)$ \\
\hline$>60 \mathrm{~g}$ fish and fish products $(5 \mathrm{I})$ & & & & \\
\hline
\end{tabular}

Data are shown as median (range).

Different superscript letters denote significant differences in the same column $(p<0.00 \mathrm{I})$ (ANOVA, Tukey's test). 
Table 5. lodine intake, urinary iodine excretion, serum thyroid-stimulating hormone (TSH) and serum free thyroxine ( $\left.T_{4}\right)$ in relation to dairy and fish intakes in Bergen

\begin{tabular}{|c|c|c|c|c|}
\hline Intake per day (\% of studied groups) & $\begin{array}{l}\text { lodine intake } \\
\left(\mu \mathrm{g} \mathrm{day}^{-1}\right)\end{array}$ & $\begin{array}{l}\text { Urinary iodine } \\
\left(\mu \mathrm{g} 24 \mathrm{~h}^{-1}\right)\end{array}$ & 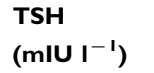 & $\begin{array}{l}\text { Free } T_{4} \\
\left(\text { pmol I}^{-1}\right)\end{array}$ \\
\hline$<150 \mathrm{~g}$ milk and dairy products and & $47(30-75)^{\mathrm{a}}$ & $44(19-186)^{a}$ & $1.7(1.0-4.2)$ & $12.3(9.6-16.0)$ \\
\hline \multicolumn{5}{|l|}{$<60 \mathrm{~g}$ fish and fish products $(34)$} \\
\hline$<\mathrm{I} 50 \mathrm{~g}$ milk and dairy products and & $83(57-152)^{\mathrm{ab}}$ & $80(16-297)^{\mathrm{ab}}$ & $1.3(0.5-2.9)$ & $11.8(10.5-13.3)$ \\
\hline \multicolumn{5}{|l|}{$>60 \mathrm{~g}$ fish and fish products $(25)$} \\
\hline$>150 \mathrm{~g}$ milk and dairy products and & $152(68-291)^{c}$ & $173(97-215)^{c}$ & $1.0(0.6-1.9)$ & $13.7(9.7-14.8)$ \\
\hline \multicolumn{5}{|l|}{$<60 \mathrm{~g}$ fish and fish products $(2 \mathrm{I})$} \\
\hline$>150 \mathrm{~g}$ milk and dairy products and & $162(111-427)^{c d}$ & $180(57-300)^{\mathrm{cd}}$ & $1.4(1.2-2.8)$ & $12.4(10.6-14.8)$ \\
\hline$>60 \mathrm{~g}$ fish and fish products $(2 \mathrm{I})$ & & & & \\
\hline
\end{tabular}

Data are shown as median (range).

Different superscript letters denote significant differences in the same column $(p<0.00$ I) (ANOVA, Tukey's test).

or a mineral tablet (e.g. calcium or iron). Dietary supplements that may contain iodine were used by $25 \%(n=16)$ of the participants in Tromsø and by $20 \%(n=9)$ of the participants in Bergen.

\section{Discussion}

This study shows a clear influence of the intake of milk and dairy products and fish and fish products on the iodine nutrition of participants in Tromsø and Bergen. The intake of iodine in the diet and the iodine concentration in the morning urine of participants in Tromsø were found to be in the range of sufficient iodine intake, whereas the dietary iodine intake and urinary iodine excretion of participants in Bergen were in the range of mild iodine deficiency (7).

Participants selected in the present studies cannot be considered to be representative of the average Norwegian population, owing to the relatively low number of participants and the selection criteria. The two studies indicate, nevertheless, that the ranges of iodine intake evaluated by the dietary intake or the urinary iodine excretion are wide and that there may exist population groups with a very low average intake of iodine.

Based on the common understanding that the iodine concentration in most foodstuffs is low and that only a few food items are regarded as good sources of iodine, the frequency and the amount of intake of these iodine-rich sources are of great importance. In general, no dietary survey methods exist today allowing estimation of the dietary intake of one or more individuals without weaknesses being connected to the data. Estimating the intake of specific nutrients, such as iodine, is further complicated by the fact that one of the two major sources of the element, i.e. fish, is normally not eaten daily. This makes it important to register food intake over a given period. This study used a validated FFQ (15-18) asking about last year's consumption of food in the Tromsø group and FFQ asking only about last month's dietary intake in the Bergen group. Although this sets limitations to the comparability of the two sets of dietary data, the authors believe that the results reflect the actual intake of the most iodine-rich foods in the diet of the two groups. The largest limitation of the study is the FFQ used in the Bergen group, which did not include questions about the intake of iodine-poor foods. The daily iodine contribution from such foods was calculated to be $27 \pm 9 \mu \mathrm{g}$ in the Troms $\varnothing$ group. Thus, $30 \mu \mathrm{g}$ iodine was added to the intake calculations of the Bergen group to ensure that their iodine intake was not underestimated. The overall risk of excessive iodine intake was not prominent in the present study, despite some high consumers of fish having an average intake exceeding $450 \mu \mathrm{g}$ day $^{-1}$.

Supplements containing iodine, seaweed and iodized salt are sources of iodine that may contribute considerable amounts of iodine in the diet (24). In the present study the contribution of iodine from dietary supplements or from iodized salt was not included in the calculation of the individuals' iodine intake. There is no available documentation showing the extent to which and in what amount the vitamin and mineral supplements contain iodine in Norway. However, it is reasonable to assume that about $25 \%$ of such supplements contain $70-150 \mu \mathrm{g}$ I per tablet (Margaretha Haugen, pers. commun.). In Norway the iodine contribution from iodized salt is considered to be insignificant (9) because only 
some brands of table salt are fortified with iodine, and regulations permit only the addition of $5 \mu \mathrm{g}$ $\mathrm{g}^{-1} \mathrm{NaCl}$. Industrial salt used in food production is not supplemented with iodine (25). With an estimated average intake of $3 \mathrm{~g}$ table salt day ${ }^{-1}$, iodine fortified salt only contributes to an intake of $15 \mu \mathrm{g}$ iodine, if used.

A single urinary iodine measurement is not representative of an individual's nutritional iodine status owing to considerable variation in the iodine excretion from day to day and during a single day in one individual (26-28). These assumptions explain in all probability the lack of relationship between iodine intake and iodine concentration in urine in Tromsø. However, the aim of the study in Tromsø was not to validate the methods used, but to evaluate the range of iodine intake.

The significant correlation between iodine intake and iodine excretion in Bergen strengthens, nevertheless, the idea that the methods used in Bergen could describe the subjects' iodine nutrition at the time of measurement. Lower correlation coefficients ( 0.34 for men and 0.43 for women) were found in a study from the Netherlands where 3 day food records were correlated with the first $24 \mathrm{~h}$ urine collection (29). In other studies correlations between 0.24 and 0.66 have been reported $(20,30,31)$.

A recent study of a representative group of Norwegians $(n=2672)$ showed that milk and dairy products, and fish and fish products were the main sources of iodine in the Norwegian diet, contributing about $80 \%$ of the iodine intake (11). The contribution of iodine from milk and dairy products, and fish and fish products in the present study was within the same ranges as were found in the above-mentioned study of Norwegians (11), with the exception of the participants from Bergen with iodine intake $<70 \mu \mathrm{g}$ day $^{-1}$. In other European countries, i.e. UK, Denmark and Finland, the contribution of iodine from the above-mentioned sources was approximately 55\% (32-34). In the UK meat products were also an important source of iodine, accounting for more than $20 \%$ of the iodine intake (32). In Finland iodized salt and eggs provided about $20 \%$ and $15 \%$ of the iodine intake, respectively (34). In the Netherlands the main source of iodine has been shown to be the iodized salt in bread (35).

Dietary iodine is an important regulator of the activity of the normal thyroid gland, and changes in iodine intake may alter the risk or modulate thyroid diseases (4). Serum levels of TSH, $\mathrm{T}_{3}$, and free and protein-bound $\mathrm{T}_{4}$ reflect the long-term iodine intake and subjects are expected to show signs of elevated TSH when iodine intake is low (7). Although a considerable number of participants in Tromsø and Bergen demonstrated iodine intake or urinary iodine concentration below the recommended values, all had serum TSH and free $\mathrm{T}_{4}$ within the laboratory reference range. Elevated TSH (4.0-9.9 mIU $1^{-1}$ ) was only found in a single participant in Bergen. The serum level of free $T_{4}$ was 10.7 pmol $1^{-1}$ in this participant and the dietary iodine intake data $\left(30 \mu \mathrm{g} \mathrm{day}^{-1}\right)$ and the iodine excretion $(33 \mu \mathrm{g}$ $24 \mathrm{~h}^{-1}$ ) confirmed the probability of iodine insufficiency. Although this was just one participant, the study in Bergen as well as in Tromsø showed a weak trend towards increasing TSH level in serum with decreasing level of iodine intake or urinary iodine content. Smoking has been reported to cause a slight decrease in serum TSH levels (36-38), as was also found in the present study. However, significant differences were not found for serum TSH between non-smokers and smokers in Tromsø.

This is the first study in Norway evaluating the iodine status of population groups by combining an estimation of iodine intake with urinary iodine concentrations and the serum levels of TSH and free $\mathrm{T}_{4}$. Based on the common understanding that the iodine concentration in most foods is low and only a few food items are regarded as good sources of iodine, the frequency and amount of intake of these dietary iodine sources are of great importance. Although there is a wide range of iodine concentrations in fish and fish products, and seasonal variations of iodine concentration in milk and dairy products, a regular intake of fish and fish products, milk and dairy products is of utmost importance to achieve the recommended daily intake of iodine from the diet. Although the two studies have some methodological weaknesses, they indicate that even in a country considered iodine replete $(9,11)$ there may exist population groups with a very low average intake of iodine. The iodization of table salt in Norway is too low to secure sufficient iodine intake for such groups. These findings highlight the importance of investigating risk groups more closely.

\section{Acknowledgements}

The Norwegian Research Council (NFR) is thanked for financially supporting this work (project no. 120824/112). 
The skilled assistance of Edel Elvevoll, Bjarne Østerud and their technical staff during the study carried out in Tromsø was highly appreciated. Berit Engen Solli is acknowledged for skilful technical assistance with the iodine analyses. Betty Irgens and Jacob Wessel are acknowledged for technical assistance with the blood sampling and the creatinine analysis in Bergen. The staff at the Hormone Laboratory, Tromsø University Hospital and Bergen University Hospital are thanked for technical assistance. The authors also wish to thank all participants for their excellent co-operation.

\section{References}

1. Hurrell RF. Bioavailability of iodine. Eur J Clin Nutr 1997; 51: S9-12.

2. Hetzel BS. Iodine deficiency disorders (IDD) and their eradication. Lancet 1983; ii: 1126-9.

3. Delange F. The disorders induced by iodine deficiency. Thyroid 1994; 4: 107-28.

4. Laurberg P, Nøhr SB, Pedersen KM, Hreidarsson AB, Andersen S, Pedersen B, et al. Thyroid disorders in mild iodine deficiency. Thyroid 2000; 10: 951-63.

5. Delange F, Burgi H, Chen ZP, Dunn JT. World status of monitoring of iodine deficiency disorders control programs. Thyroid 2002; 12: 915-24.

6. Hetzel BS. Eliminating iodine deficiency disorders - the role of the International Council in the global partnership. Bull World Health Organ 2002; 80: 5.

7. World Health Organization (WHO)/United Nations Children's Fund (UNICEF)/International Council for Control of Iodine Deficiency Disorders (ICCIDD). Assessment of the iodine deficiency disorders and monitoring their elimination. A guide for programme managers. 2nd edn. WHO/NHD/01.1. Geneva: WHO; 2001. p.1-107.

8. Devold O, Batt F, Closs K, Backer J. En strumaundersøkelse fra Modum. N Mag Lægev 1937; 7: 900-37 (In Norwegian.).

9. Frey H, Rosenlund B, Try K, Theodorsen L. Urinary excretion of iodine in Norway. In: Delange F, ed. Iodine deficiency in Europe. New York: Plenum Press; 1993. p. 297-300.

10. Sandström B, Aro A, Becker W, Lyhne N, Pedersen JI, Pórsdóttir I. Nordiska närings-rekommendationer 1996. (Nordic nutrition recommendations 1996). Copenhagen: Nordic Council of Ministers, Nord; 1996. p. 28. (In Swedish.)

11. Dahl L, Meltzer HM, Johansson L, Julshamn K. The iodine content of Norwegian foods and diets. 2003; Publ Health Nutr; In press.

12. Dahl L, Opsahl JA, Meltzer HM, Julshamn K. Iodine concentration in Norwegian milk and dairy products. $\mathrm{Br}$ J Nutr 2003; 90: 679-85.

13. Julshamn K, Dahl L, Eckhoff K. Determination of iodine in seafood by inductively coupled plasma/mass spectrometry. J AOAC Int 2001; 84: 1976-83.

14. Ministry of Health in Norway. In: Generell forskrift for produksjon og frambud m.v. av næringsmidler. (Regulation of general production of food offered to consu- mers). 2002; retrieved from http://www.snt.no/ rettsregler/forskrifter/hd-19830708-1252.html (In Norwegian.)

15. Nes M, Frost Andersen L, Solvoll K, Sandstad B, Hustvedt B, Løvø A, Drevon CA. Accuracy of a quantitative food frequency questionnaire applied in elderly Norwegian women. Eur J Clin Nutr 1992; 42: 809-21.

16. Solvoll K, Lund-Larsen K, Søyland E, Sandstad B, Drevon CA. A quantitative food frequency questionnaire evaluated in a group of dermatologic outpatients. Scand J Nutr 993; 37: 150-5.

17. Andersen LF, Solvoll K, Johansson LRK, Salminen I, Aro A, Drevon CA. Evaluation of a food frequency questionnaire with weighed records, fatty acids and alpha-tocopherol in adipose tissue and serum. Am J Epidemiol 1999; 150: 75-87.

18. Andersen LF, Solvoll K, Drevon CA. Very long-chain n3 fatty acids as biomarkers for intake of fish and n-3 fatty acids concentrates. Am J Clin Nutr 1996; 64: 30511.

19. Pedersen KM, Laurberg $P$, Nöhr S, Jørgensen A, Andersen S. Iodine in drinking water varies by more than 100-fold in Denmark. Importance for iodine content of infant formulas. Eur J Endocrinol 1999; 140: 400-3.

20. Rasmussen LB, Ovesen L, Bülow I, Jørgensen T, Knudsen N, Laurberg P, Perrild H. Dietary iodine intake and urinary iodine excretion in a Danish population: effect of geography, supplements and food choice. Br J Nutr 2002; 87: 61-9.

21. Johansson L, Solvoll K. Norkost 1997. Landsomfattende kostholdsundersøkelse blant menn og kvinner i alderen 16-79 år. (National dietary survey among males and females, 16-79 years). Publication No. 2. Oslo: Norwegian National Council of Nutrition and Physical Activity; 1999. (In Norwegian.)

22. Fecher PA, Goldmann I, Nagengast A. Determination of iodine in food samples by inductively coupled plasma mass spectrometry after alkaline extraction. J Anal At Spectrom 1998; 13: 977-82.

23. Bartels H, Böhmer M. Micro-determination of creatinine. Clin Chem Acta 1971; 32: 81-5.

24. Tokudome S, Tokudome Y, Moore MA. Dietary iodine sources other than fish. Eur J Clin Nutr 2002; 56: 467-8.

25. Frey H. Iodine status in Scandinavia. Acta Pharmacol Toxicol 1986; 59: 111-5.

26. Rasmussen LB, Ovesen L, Christiansen E. Day-to-day and within-day variation in urinary iodine excretion. Eur J Clin Nutr 1999; 53: 401-7.

27. Als C, Helbling A, Peter K, Haldimann I, Zimmerli B, Gerber H. Urinary iodine concentration follows a circadian rhythm: a study with 3023 spot urine samples in adults and children. J Clin Endocrinol Metabol 2000; 85: $1367-9$.

28. Andersen S, Pedersen K, Pedersen I, Laurberg $P$. Variations in urinary iodine excretion and thyroid function. A 1-year study in healthy men. Eur $\mathbf{J}$ Endocrinol 2001; 144: 461-5. 
29. Brussaard J, Brants HAM, Hulshof KFAM, Kistemaker $\mathrm{C}$, Lowik MRH. Iodine intake and urinary excretion among adults in the Netherlands. Eur J Clin Nutr 1997; 51: S59-62.

30. Nelson M, Quayle A, Phillips D. Iodine intake and excretion in two British towns: aspects of questionnaire validation. Hum Nutr Appl Nutr 1987; 41A: 187-92.

31. Kim JY, Moon SJ, Kim KR, Sohn CY, Oh JJ. Dietary iodine intake and urinary iodine excretion in normal Korean adults. Yonsei Med J 1998; 39: 355-62.

32. Lee SM, Lewis J, Buss DH, Holcombe GD, Lawrance PR. Iodine in British foods and diets. Br J Nutr 1994; 72: $435-46$.

33. Rasmussen LB, Ovesen L, Bülow I, Jørgensen T, Knudsen N, Laurberg P, Perrild H. Evaluation of a semi-quantitative food frequency questionnaire to estimate iodine intake. Eur J Clin Nutr 2001; 55: 287-92.

34. Varo P, Saari E, Koivistoinen P. Iodine in Finnish foods. Int J Vit Nutr Res 1982; 52: 80-9.

35. Brussaard J, Brants H, Hulshof K, Kistemaker C, Lowik $M$. Iodine intake and urinary excretion among adults in the Netherlands. Eur J Clin Nutr 1997; 51: S59-62.
36. Ericsson UB, Lindgärde F. Effects of cigarette smoking on thyroid function and the prevalence of goitre, thyrotoxicosis and autoimmune thyroiditis. J Intern Med 1991; 229: 67-71.

37. Petersen K, Lindstedt G, Lundberg PA, Bengtsson C, Lapidus L, Nyström E. Thyroid disease in middle-aged and elderly Swedish women: thyroid-related hormones, thyroid dysfunction and goitre in relation to age and smoking. J Intern Med 1991; 229: 407-14.

38. Vestergaard P. Smoking and thyroid disorders - a meta analysis. Eur J Endocrinol 2002; 146: 153-61.

\section{Lisbeth Dahl}

National Institute of Nutrition and Seafood Research (NIFES), PO Box 176, Sentrum NO-5804, Bergen, Norway,

Tel. +4755905। 13,

Fax: +4755905299

E-mail: lisbeth.dahl@nifes.no 